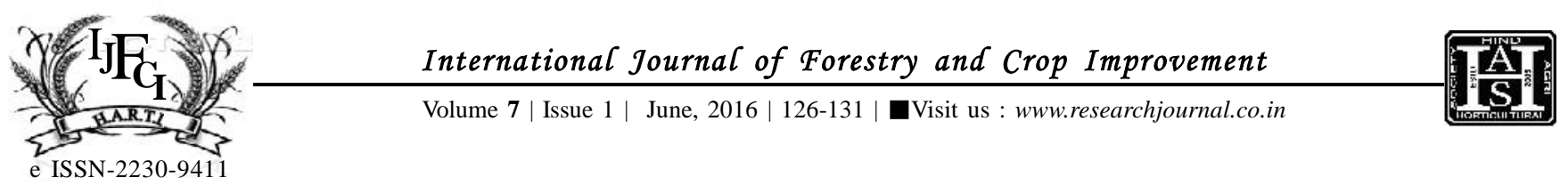

A Case Study

DOI: $10.15740 / \mathrm{HAS} / \mathrm{IJFCI} / 7.1 / 126-131$

\title{
Agroforestry practices and concepts in sustainable land use systems in India
}

\author{
SAURABH VERMA, VinOD Singh, D.K. VERMAand S.P. GIRI
}

\begin{abstract}
Agroforestry has been defined as a dynamic ecologically based natural resources management system that through the integration of trees on farms and in the agricultural landscape diversifies and sustains production for increased social, economic and environmental benefits for land users at all levels. This paper highlighted agroforestry practices and concepts in sustainable land use systems. The benefit derivable from the interface between forest trees and agricultural crops are enormous. They include the optimal use of land for both agricultural and forestry production on a sustainable basis including the improvement of the quality of soil. This is in addition to the socio-economic benefits that are accruable from agroforestry. Indeed the advantage of agroforestry is all encompassing and germane to a sustainable production system and livelihood.
\end{abstract}

KEY WORDS : Agroforestry, Sustainable, Land use systems, Agrisilvi, Silvipastoral, Agrisilvipastoral

HOW TO CITE THIS ARTICLE : Verma, Saurabh, Singh, Vinod, Verma, D.K. and Giri, S.P. (2016). Agroforestry practices and concepts in sustainable land use systems in India. Internat. J. Forestry \& Crop Improv., 7 (1) : 126-131, DOI: 10.15740/HAS/IJFCI/7.1/126-131.

ARTiCle ChronicAL : Received : 02.02.2016; Accepted : 29.05.2016 